\title{
Evaluation of the mineral content of winter wheat
}

Keywords: winter wheat, mineral content, iron, zinc

\section{Introduction}

Winter wheat is one of the most important crops produced worldwide, one of the 'big three' cereals. ${ }^{1}$ By consuming wheat, $30 \%$ of the daily calorie intake can be provided. Wheat offers variable utilization possibilities ranging from winter wheat flour to flour blends made of wheat and other cereal or pseudo cereal flours, which result in different bread products (pan bread, flat bread) depending on the food consumption habits of the given region. As a consequence, quality parameters also vary but the basic content is permanent with the mineral content being the most important parameter.

Today research and application in food and nutritional sciences increasingly emphasizes the chemical composition of winter wheat as basic food regarding both its organic and inorganic macro-and micro components. ${ }^{2}$ This consideration is the result of several factors among which the increase of analytical possibilities has to be emphasized in addition to factors related to production technology that often change (cultivars, hybrids, crop protection, fertilization, frequency of extreme weather conditions). Consequently, researchers in the past two decades began to focus on the issue whether the chemical composition, fodderand nutritional physiological quality of plant products change. ${ }^{3}$ It is considered especially important to determine how the mineral content of winter wheat changed in the past decades. Since mineral content is the quality indicator that can be used trustworthily to estimate and interpret long-term effects (fertilization, organic and mineral fertilization, crop protection, $\mathrm{SO}_{2}$ emission, atmospheric $\mathrm{SO}_{2}$ deposition, accompanying elements of fertilization, climate change, and change in cultivars) based on the data of the experimental samples. In other researches phosphorus, calcium, potassium, magnesium, iron, manganese, zinc and copper were studied in addition to selenium which is physiologically important in human nutrition. There are less data for other elements as well. As the importance of food quality increases, the study of potentially toxic elements $(\mathrm{Cd}, \mathrm{Cr}, \mathrm{Pb})$ is also relevant especially if the daily fiber intake needs to be increased with whole meal flours or wheat bran.

While comparing international data certain authors provided exact data $^{4}$ but others found that the concentration of different elements was wide-ranging. ${ }^{5}$ The data reported on the zinc content of winter wheat samples from different regions of the world varied between 21.9 and $38.5 \mathrm{mg} / \mathrm{kg}^{6}$ which means these values were the following: $26.3-38.5$ in Germany, 28.0 in Denmark and Sweden, 32.6 in Finland, 21.9-27 in the USA, 22.0 in Turkey and $26.0 \mathrm{mg} / \mathrm{kg}$ in India. These data showed a considerably lower difference than the data published by Piironen et al. ${ }^{4}$ and they are closer to the data reported in article. ${ }^{5}$

The published results from the processed samples of the Rothamsted Broadbalk long-term wheat experiment found in 1843 is of note. ${ }^{7}$ According to them the mineral content of the samples had not changed until 1965 but through the spread of semi-dwarf cultivars some elements $(\mathrm{Cu}, \mathrm{Mg}, \mathrm{Zn})$ decreased with $15-25 \%$ until today. Similar tendencies can be found in the results of the Hungarian researches. ${ }^{8}$ Researches in Finland found that most mineral and trace element contents of cereal products, fruits and vegetables have changed
Volume 4 Issue 4 - 2017

\author{
Zoltán Györi \\ UNIVERSITY OF DEBRECEN, HUNGARY
}

Correspondence: Zoltán Győri, University of Debrecen, Institute of Nutritional Sciences, Hungary H-4032, Debrecen, I 38, Böszörmenyi str, Tel +36 52 508444/88406,Email gyori.zoltan@unideb.hu

Received: December 19, 2016 | Published: July 12, 2017

significantly in Finland during the past 30 years except Selenium. ${ }^{9}$ It was determined during the comparison of products from organic and intense production that wheat has a higher mineral content ${ }^{10}$ in case of organic production especially when its production is combined with the growing of ancient cultivars/species. ${ }^{11-13}$ According to the data published on cultivars grown in different ecological conditions ${ }^{14,15}$ there is a significant difference between the iron and zinc content of different bread flour genotypes but there is no such difference in the selenium content. The results of the Swedish experiments showed ${ }^{16}$ that the decrease of air pollution resulted in a significant decline in lead and cadmium levels of wheat samples while as a consequence of the NKP fertilization treatment the copper and iron content declined. A contrary result was also reported ${ }^{17,18}$ since after Nitrogen fertilization iron, zinc and copper contents increased. Today, one of our most urgent problems is the effect of climate change, especially the effect of the increasing carbon dioxide level of the atmosphere on the zinc and iron content of $\mathrm{C} 3$ plant products and legumes ${ }^{19}$ since this decrease leads to a change (decrease) of content in the basic diet of millions of people, which increases undernourishment in terms of these two elements. Therefore it is justified for us to make efforts in the field of biofortification. ${ }^{20-22}$

\section{Acknowledgements}

None.

\section{Conflict of interest}

The author declares no conflict of interest.

\section{References}

1. Wrigley C. Assessing and managing quality at all stage of the grain chain. In: Wrigley C, editors. Cereal Grains Assessing and Managing Quality. 2nd ed. United Kingdom: Woodhead Publishing, Kidlington; 2017. p. $3-25$.

2. Poutanen K, Shepherd R, Shewry PR, et al. More of the grain-progress in the health grain project for healthy cereals foods. Cereal Foods World. 2010;55(2):79-84.

3. Shewry PR. Wheat. Journal of Experimental Botany. 2009;60(6):15371553.

4. Piironen. Wheat: characteristics and quality requirements. In: Wrigly $\mathrm{CW}$, et al. editors. Cereal Grains Assessing and Managing Quality. Oxford, Cambridge, UK: Woodhead Publishing; 2009. p. 59-103. 
5. Kent NL. Technology of cereals. 4th ed. UK: Woodhead publishing; 1994 $316 \mathrm{p}$

6. Scherz H, Kirchhoff E. Trace elements in foods: Zinc contents of raw foods-A comparison of data originating from different geographical regions of the world. Journal of Food Composition and Analysis. 2006;19(5):420 433.

7. Fan MS, Zhao FJ, Fairweather Tait SJ, et al. Evidence of decreasing mineral density in wheat grain over the last 160years. J Trace Elem Med Biol. 2008;22(4):315-324.

8. Győri Z. Variation in the mineral content of winter wheat in Hungary between 1839 and 2005. Agrokémiaés Talajtan. 2015;64(1):189-198.

9. Ekholm, Reinivuo PH, Mattila P, et al. Changes in the mineral and trace element contents of cereals, fruits and vegetables in Finland. Journal of Food Composition and Analysis. 2007;(20):487-495.

10. Hussain A, Larsson H, Kuktaite R, et al. Mineral composition of organically grown wheat genotypes: Contribution to daily minerals intake. Int J Environ Res Public Health. 2010;7(9):3442-3456.

11. Oury FX, Leenhardt F, Rémésy C, et al. Genetic variability and stability of grain magnesium, zinc and iron concentrations in bread wheat. European Journal of Agronomy. 2006;25(2):177-185.

12. Suchowilska E, Wiwart M, Kandler W, et al. A comparison of macro- and microelement concentrations in the whole grain of four Triticum species. Plant Soil Environment. 2012;58(3):141-147.

13. Bálint AF, Kovács G, Erdei L, et al. Comparison of the $\mathrm{Cu}, \mathrm{Zn}, \mathrm{Fe}, \mathrm{Ca}$ and $\mathrm{Mg}$ contents of the grains of wild, ancient and cultivated wheat species. Cereal Research Communications. 2001;29(3-4):375-382.

14. Szira F, Monostori I, Galiba G, et al. Micronutrient contents and nutritional values of commercial wheat fluors and fluors of field-grown wheat varieties-A survey in Hungary. Cereal Research Communications. 2014;42(2):293-302.
15. Zhao FJ, Su YK, Dunham SJ, et al. Variation in mineral micronutrient concentrations in grain of wheat lines of diverse origin. Journal of Cereal Science. 2009;49(2):290-295.

16. Kirchmann H, Mattson L, Eriksson J. Trace element concentration in wheat grain: Results from the Swedish long-term soil fertility experiments and national monitoring program. Environ Geochem Health. 2009;21(5):561571.

17. Shi R, Zhang Y, Chen X, et al. Influence of long-term nitrogen fertilization on micronutrient density in grain of winter wheat (Triticumaestivum L.). Journal of Cereal Science. 2010;51(1):165-170.

18. Kutman UB, Yildiz B, Cakmak I. Improved nitrogen status enhances zinc and iron concentrations both in the whole grain and the endosperm fraction of wheat. Journal of Cereal Science. 2011;53(1):118-125.

19. Myers SS, Zanobetti A, Kloog I, et al. Increasing $\mathrm{CO}_{2}$ threatens human nutrition. Nature. 2014;511(7503):139-142.

20. Marschner H. Mineral Nutrition of Higher Plants. 2nd ed. London, UK Academic Press; 1995. 645 p.

21. Rengel Z, Batten GD, Crowley DE. Agronomic approaches for improving the micronutrient density in edible portions of field crops. Field Crops Research. 1995;60(1-2):27-40.

22. Chugh V, Dhaliwal HS. Biofortification of Staple Crop Chapter 9. In: Bhullar GS, et al. editors. Agricultural Sustainability Progress and Prospects in Crop Research. USA: Academic Press Elsevier; 2013. p. 177-196. 